\title{
Study on Comprehensive Decision of Urban Rail Transit Network Planning
}

\author{
Liu Sheng ${ }^{1}$ \\ ${ }^{1}$ Lanzhou jiao tong University, Lanzhou, China
}

\begin{abstract}
Based on the research and analysis of urban rail transit network planning, Determining Evaluation Index System of Urban Mass Transit Network.On this basis, the evaluation index system of network planning is established. this paper analyzes and compares the planning scheme of urban rail transit network in a city, and combines the analytic hierarchy process and the gray correlation method so that the alternatives can be discharged in good or bad order.The ranking results can objectively reflect the actual situation of urban rail transit network planning, in order to solve the problem of optimal selection of urban rail transit network planning, a set of objective scheme is proposed to avoid the decision deviation caused by the defects of single decision method.
\end{abstract}

\section{Introduction}

Urban rail transit network plan decision is the key step in the urban rail transit network planning, which is the basis of project optimization. The planning of urban rail transit network planning is mainly based on qualitative analysis [1], [2].This paper is based on the analysis of urban rail transit network planning, using analytic hierarchy process (AHP) combined with the GRAY correlation method, and to establish a scientific and rational evaluation index system, the comprehensive analysis of each scheme for qualitative and quantitative solution should selected from the different options for the best program.

Urban rail transit network evaluation is

different from the general urban road network and regional highway network evaluation.To evaluate the urban rail transit network, we must consider various characteristic factors and establish a complete, scientific and comprehensive evaluation system with the actual situation of the urban rail network. In addition, the scale of the rational control index system is also an important aspect [3].According to the above principle, using AHP basic principle, to establish a set of evaluation index system[4], [5] In the specific planning, according to the need for the following table to the appropriate increase or decrease.

\section{The urban rail transit network based on Ahp - Gray comprehensive decision method}

The factors that affect the urban rail transit network are expressed as hierarchical structure, and the indicators have qualitative and quantitative indicators.In the following,we combine the AHP method and the GRAY method to establish the decision model of urban rail transit network.

\subsection{Index weight assignment method-AHP}

Analytic hierarchy process (AHP) was proposed in the 1970 s by the United States operations researcher T.L.satty for the first time. The method is a combination of quantitative and qualitative methods.it is often used in combination with other evaluation methods to determine the weight of evaluation index $[6,7]$.

AHP method of the basic steps:(1)Create a hierarchical hierarchy model;(2) To construct judgment matrix;(3) Determine the hierarchical weight value;(4) Consistency test of the judgment matrix;

The matrix deviates from the consistency indicator C.I., as in equation (1).

$$
\text { C.I. }=\frac{\lambda_{\max }-\mathrm{n}}{\mathrm{n}-1}
$$

Random Consistency Ratio C.R., as in equation (2).

$$
\text { C.R. }=\frac{\text { C.I. }}{\text { R.I. }}<0.1
$$

(5) Calculate the weight of the elements of each layer.

\subsection{The optimal decision-making program-GRAY}

Gray correlation method(GRAY) is a multi-factor integrated decision-making method.It can make full use of the existing information to reduce the error by using the Gray correlation degree as the measure, and provide a simple and applicable method for the optimization decision making [8], [9] In the above analysis, this paper establishes the optimization model of urban rail transit network planning and evaluation decision-making system, 
and puts forward a decision method based on Gray relational decision-making method.

\subsubsection{Determine the decision matrix}

Assume that $\mathrm{A}$ is a set of alternatives of decision-making $\mathrm{A}=\left\{\mathrm{a}_{1} \mathrm{a}_{2, \ldots} \mathrm{a}_{\mathrm{m}}\right\}, \mathrm{V}$ is a set of decision matrices $\mathrm{V}=$

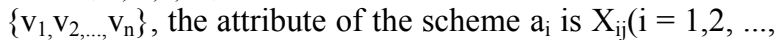
$\mathrm{m} ; \mathrm{j}=1,2, \ldots, \mathrm{n})$, then the matrix $\mathrm{X}=\left(\mathrm{x}_{\mathrm{ij}}\right)_{\mathrm{m} \times \mathrm{n}}$ is the decision matrix of the set $\mathrm{A}$ of the scheme.

\subsubsection{Evaluation index matrix standardized treatment}

In the standardization of qualitative indicators and quantitative indicators to be used when the different treatment methods.

Quantitative function of the benefit index $V_{j}$ :

$$
\mathrm{x}_{\mathrm{ij}}=\frac{\mathrm{x}_{\mathrm{ij}}}{\max \mathrm{x}_{\mathrm{ij}}}
$$

Quantitative function of cost index $V_{j}$ :

$$
\mathrm{x}_{\mathrm{ij}}^{\prime}=\frac{\max _{\mathrm{ij}}+\min _{\mathrm{i} \leq \mathrm{m} \quad 1 \leq \mathrm{i} \leq \mathrm{m}}-\mathrm{x}_{\mathrm{ij}}}{\max _{\mathrm{ij}}}
$$

Quantitative function of qualitative index $\mathrm{V}_{\mathrm{j}}$ :

$$
x_{i j}^{\prime}=1-\frac{\left|q_{i j}-x_{i j}\right|}{\max \left|q_{i j}{ }_{1 \leq i \leq m} \min _{1 i j}, \max _{1 \leq \mathrm{i} \leq \mathrm{m}} x_{i j}-q_{i j}\right|}
$$

\subsubsection{Gray correlation coefficient of the program}

The gray correlation coefficient of the scheme is based on the relevance of the evaluation scheme index vector and the relative optimal index vector as the criterion of the decision-making scheme, which is derived from the gray relational decision theory[8].The gray correlation coefficient is:

$$
\min _{i j}=\frac{\min _{j}\left|x_{0 j}-x_{i j}\right|+\rho \max _{i} \max _{j}\left|x_{0 j}-x_{i j}\right|}{\left|x_{0 j}-x_{i j}\right|+\rho \max _{i} \max _{j}\left|x_{0 j}-x_{i j}\right|}
$$

In the formula, $\rho$ is the resolution coefficient, generally take 0.5 .

According to the above analysis, we can see that the gray relational coefficient matrix is

$$
\mathrm{R}=\left|\begin{array}{cccc}
\xi_{11} & \xi_{12} & \ldots & \xi_{1 \mathrm{n}} \\
\xi_{21} & \xi_{22} & \ldots & \xi_{2 \mathrm{n}} \\
\ldots & \ldots & \ldots & \ldots \\
\xi_{\mathrm{m} 1} & \xi_{\mathrm{m} 2} & \ldots & \xi_{\mathrm{mn}}
\end{array}\right|
$$

\subsection{Comprehensive decision-making model}

Evaluation index system of $\mathrm{n}$ relative to the overall goal of weight vector $\mathrm{W}=\left(\mathrm{w}_{1}, \mathrm{w}_{2}, \ldots, \mathrm{w}_{\mathrm{n}}\right)$, Then the weighting degree of the relative optimal scheme is related to each other R':

$$
\mathrm{R}^{\prime}=\mathrm{RW}=\left(\mathrm{r}_{1}, \mathrm{r}_{2} \ldots, \mathrm{r}_{\mathrm{n}}\right)
$$

In the formula, $r_{i}=\sum_{j}^{n} r_{i j} w_{j}, i=1,2, \ldots, m$.

Therefore, when $\max \left(\mathrm{r}_{1}, \mathrm{r}_{2} \ldots, \mathrm{r}_{\mathrm{n})}\right.$,Scheme for the planning of the optimal solution.

\section{Examples of comprehensive decision-makin method validation}

\subsection{Construction of line network evaluation system}

A Case Study of Urban Rail Transit Network Planning. The network planning have three programs, specific data and parties as listed in Table 2.

Table 2. Data of Urban Rail Transit Planning

\begin{tabular}{|l|c|c|c|}
\hline Index & Program 1 & Program 2 & Program 3 \\
\hline Line density & 0.73 & 0.71 & 0.75 \\
\hline $\begin{array}{l}\text { Line Passenger } \\
\text { Intensity }\end{array}$ & 2.8 & 2.7 & 2.6 \\
\hline $\begin{array}{l}\text { Convenient } \\
\text { links to core } \\
\text { cities }\end{array}$ & 8 & 7 & 7 \\
\hline $\begin{array}{l}\text { Transfer } \\
\text { coefficient }\end{array}$ & 1.41 & 1.39 & 1.34 \\
\hline Line length & 107.93 & 107.08 & 117.14 \\
\hline $\begin{array}{l}\text { Staging } \\
\text { construction } \\
\text { rationality }\end{array}$ & 8 & 7 & 7 \\
\hline $\begin{array}{l}\text { Engineering } \\
\text { difficulties or } \\
\text { ease of use }\end{array}$ & 7 & 7 & 8 \\
\hline $\begin{array}{l}\text { Feasibility of } \\
\text { project } \\
\text { implementation }\end{array}$ & 8 & 7 & 7 \\
\hline $\begin{array}{l}\text { the adaptability } \\
\text { of urban } \\
\text { landscape }\end{array}$ & 8 & 7 & 7 \\
\hline $\begin{array}{l}\text { In line with the } \\
\text { overall urban } \\
\text { development } \\
\text { plan }\end{array}$ & 8 & 8 & 7 \\
\hline $\begin{array}{l}\text { the adaptation } \\
\text { of urban land } \\
\text { use planning }\end{array}$ & 8 & 8 & 7 \\
\hline $\begin{array}{l}\text { Promote social } \\
\text { development }\end{array}$ & 8 & 7 & 7 \\
\hline $\begin{array}{l}\text { Improve the } \\
\text { people's living } \\
\text { standards }\end{array}$ & 8 & & \\
\hline
\end{tabular}

From the technical evaluation, economic evaluation, environmental evaluation, social evaluation, combined with the actual situation of a city network construction evaluation index system, see Figure 1. 


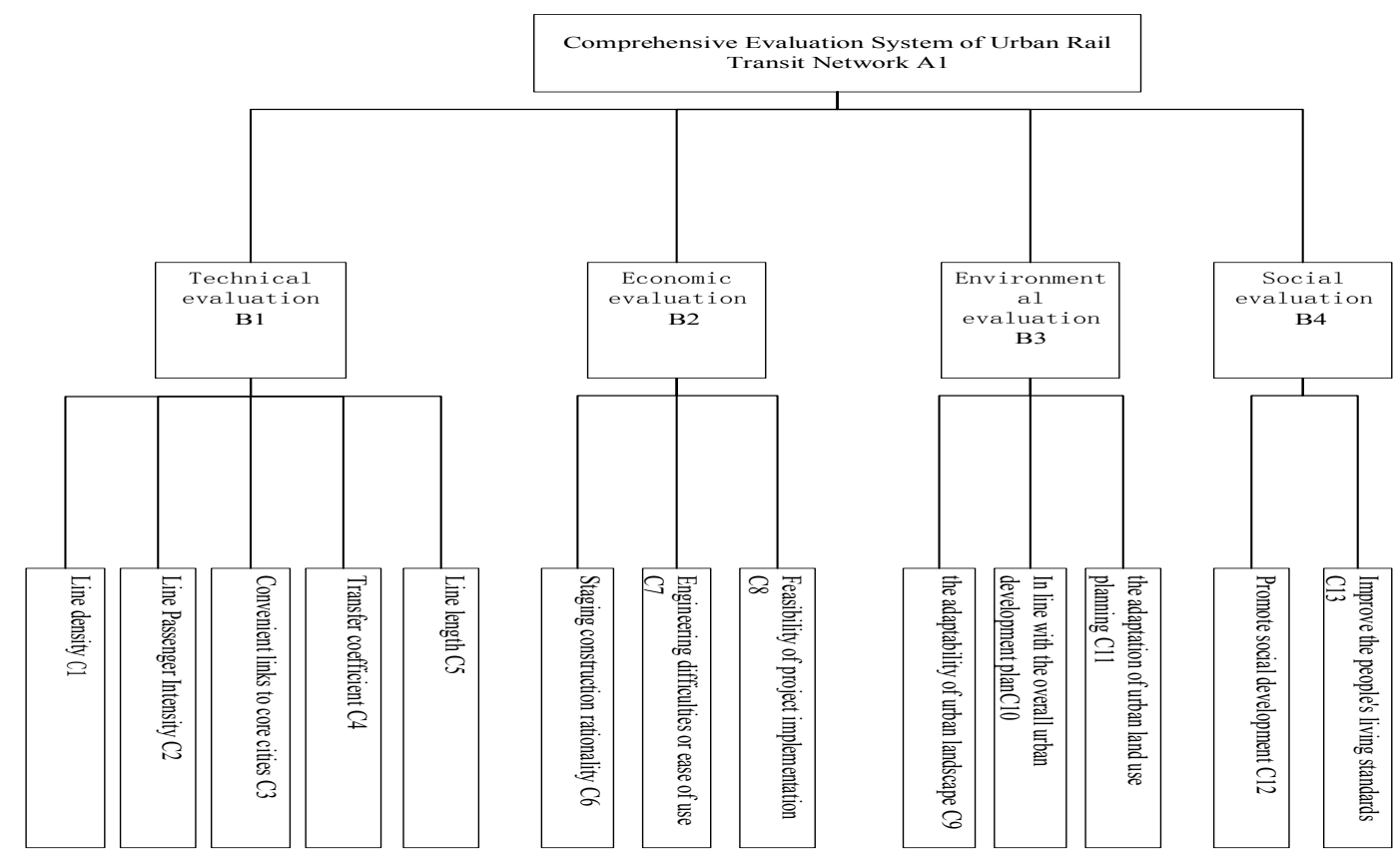

Figure 1. Evaluation Index System of Urban Rail Transit Network

\subsection{Determination of the weight of indicators}

The AHP method is used to quantify the importance of each evaluation index by using the 1-9 scale method through expert evaluation [10]. The Square root method is used to calculate the weight vector.

Two of each factor to establish judgment matrix and the matrix consistency index as shown in Table3, Table 4 shows the weight of the index system of the evaluation index system.

Table 3. Pairwise Judgment Matrix and Matrix Consistency Index

\begin{tabular}{|c|c|c|c|c|c|}
\hline $\begin{array}{l}\text { Calculate } \\
\text { the content }\end{array}$ & $\begin{array}{c}\mathrm{A}(\mathrm{B} 1, \mathrm{~B} \\
2, \mathrm{~B} 3, \mathrm{~B} 4 \\
)\end{array}$ & $\begin{array}{l}\mathrm{B} 1(\mathrm{C} \\
1, \mathrm{C} 2, \\
\mathrm{C} 3, \mathrm{C} \\
4, \mathrm{C} 5)\end{array}$ & $\begin{array}{c}\text { B2(C6 } \\
\text {,C7,C } \\
8)\end{array}$ & $\begin{array}{l}\text { B3(C } \\
9, \mathrm{C} 10 \\
, \mathrm{C} 11)\end{array}$ & $\begin{array}{c}\mathrm{B} 4(\mathrm{C} \\
12, \mathrm{C} \\
13)\end{array}$ \\
\hline $\begin{array}{l}\text { Judgment } \\
\text { matrix }\end{array}$ & $\begin{array}{lll}1 & 4 & 3 \\
5 & & \\
1 / 4 & 1 \\
1 / 3 & 1 \\
1 / 3 & 3 & 1 \\
2 & & \\
1 / 5 & 1 \\
1 / 2 & 1\end{array}$ & $\begin{array}{ll}1 & \\
1 / 2 & 4 \\
3 & 3 \\
2 & 1 \\
7 & 5 \\
5 & \\
1 / 4 & \\
1 / 7 & 1 \\
1 / 2 & \\
1 / 3 \\
1 / 3 \\
1 / 5 & 2 \\
1 & 1 \\
1 / 3 & \\
1 / 5 & 3 \\
1 & 1\end{array}$ & 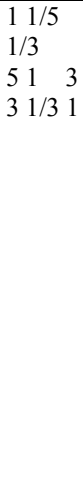 & $\begin{array}{ll}11 / 3 \\
1 / 3 \\
31 \\
1 & \\
3 & 1 \\
1 & \end{array}$ & $\begin{array}{l}11 / 3 \\
31\end{array}$ \\
\hline
\end{tabular}

\begin{tabular}{|l|l|l|l|l|l|}
\hline The & 0.549 & 0.263 & 0.105 & 0.143 & 0.250 \\
geometric & 0.106 & 0.475 & 0.637 & 0.429 & 0.750 \\
average & 0.236 & 0.055 & 0.258 & 0.429 & \\
& 0.109 & 0.090 & & & \\
& & 0.110 & & & \\
\hline $\begin{array}{l}\text { Maximum } \\
\text { eigenvalue }\end{array}$ & 4.058 & 5.073 & 3.039 & 3 & 2 \\
\hline $\begin{array}{l}\text { Relative } \\
\text { consistenc } \\
\text { y index }\end{array}$ & 0.019 & 0.018 & 0.0191 & 0 & 0 \\
\hline $\begin{array}{l}\text { Consistenc } \\
\text { y indicator }\end{array}$ & $\begin{array}{c}0.021<0 \\
.1\end{array}$ & $\begin{array}{l}0.016 \\
<0.1\end{array}$ & 0.033 & $0<0.1$ & $0<0$. \\
\hline
\end{tabular}

Table 4. Urban index system single layer relative weight

\begin{tabular}{|c|c|c|c|c|}
\hline \multicolumn{2}{|c|}{$\begin{array}{l}\text { Index system } \\
\text { stratification }\end{array}$} & \multicolumn{3}{|c|}{ Single layer weight } \\
\hline \multirow{9}{*}{ 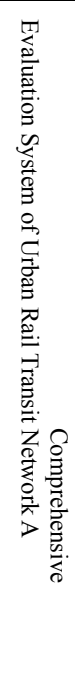 } & \multirow{5}{*}{$\begin{array}{l}\text { Technical } \\
\text { evaluation B1 }\end{array}$} & Line density $\mathrm{C} 1$ & 0.549 & 0.263 \\
\hline & & $\begin{array}{l}\text { Line Passenger } \\
\text { Intensity } \mathrm{C} 2\end{array}$ & & 0.475 \\
\hline & & $\begin{array}{l}\text { Convenient } \\
\text { links to core } \\
\text { cities C3 }\end{array}$ & & 0.055 \\
\hline & & $\begin{array}{l}\text { Transfer } \\
\text { coefficient C4 }\end{array}$ & & 0.090 \\
\hline & & Line length C5 & & 0.110 \\
\hline & \multirow[t]{3}{*}{$\begin{array}{l}\text { Economic } \\
\text { evaluation B2 }\end{array}$} & $\begin{array}{l}\text { Staging } \\
\text { construction } \\
\text { rationality C6 }\end{array}$ & 0.106 & 0.105 \\
\hline & & $\begin{array}{l}\text { Engineering } \\
\text { difficulties or } \\
\text { ease of use } \mathrm{C} 7\end{array}$ & & 0.637 \\
\hline & & $\begin{array}{l}\text { Feasibility of } \\
\text { project } \\
\text { implementation } \\
\text { C8 }\end{array}$ & 0.236 & 0.258 \\
\hline & $\begin{array}{l}\text { Environmental } \\
\text { assessment B3 }\end{array}$ & $\begin{array}{l}\text { the adaptability } \\
\text { of urban } \\
\text { landscape C9 }\end{array}$ & 0.236 & 0.143 \\
\hline
\end{tabular}




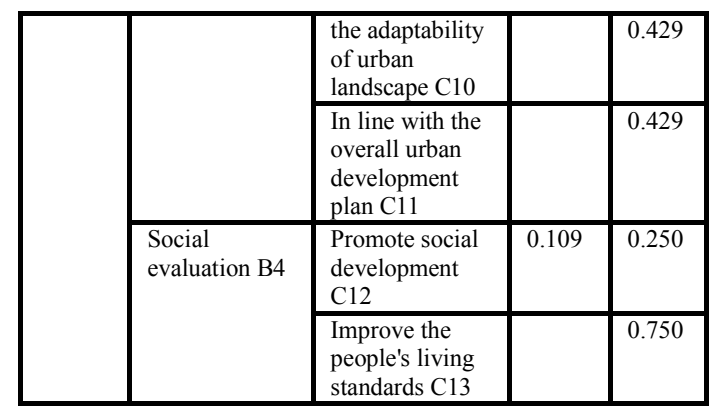

The combined weights of the layers are calculated, i.E. $\mathrm{W}=(0.144,0.261,0.030,0.050,0.060,0.011,0.068,0.0273,0$. 034,0.101,0.101,0.027,0.0818).

\subsection{According to the gray method to give each program indicators and indicators of optimal correlation matrix}

\subsubsection{Determine the decision matrix}

$$
\mathrm{X}=\left|\begin{array}{lllllllllllll}
0.73 & 2.8 & 8 & 1.41 & 107.93 & 8 & 7 & 8 & 8 & 8 & 8 & 8 & 8 \\
0.71 & 2.7 & 7 & 1.39 & 107.08 & 8 & 7 & 7 & 7 & 8 & 8 & 7 & 7 \\
0.75 & 2.6 & 7 & 1.34 & 117.14 & 7 & 8 & 7 & 7 & 7 & 7 & 7 & 7
\end{array}\right|
$$

3.3.2 After the normalized processing, the comprehensive decision matrix is obtained

$$
\begin{aligned}
& \begin{array}{llllllllllll}
0.97 & 1 & 1 & 0.95 & 0.9210 .88 & 1 & 1 & 1 & 1 & 1 & 1 & 1
\end{array} \mid
\end{aligned}
$$

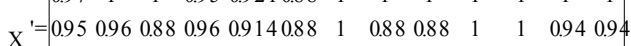

$$
\begin{aligned}
& \begin{array}{lllllllllllllllll}
1 & 0.93 & 0.88 & 1 & 1 & 1 & 0.88 & 0.88 & 0.88 & 0.88 & 0.88 & 0.88 & 0.8 \%
\end{array}
\end{aligned}
$$

3.3.3 Gray relational judgment matrix $R$, by the formula (6),

\section{References}

1. H. Ning, P. Xiangyang.Decision - making Analysis of Urban Rapid Rail Transit Planning[J].China Journal of Highway and Transport.12(3):73-81, (1999).

2. G. Xiucheng, et al.Study on Evaluation Method of Urban Rail Line Network Planning[J].Research on Urban Rail Transit,(4),pp,24-27, (2000).

3. C. Xumei, L. Fengjun, The study on the criterion system for comprehensive system for evaluation of The urban[J].City Planning Review,25(10),pp.61-64,(2001).

4. J. Jialun, Research on Comprehensive Evaluation Index System of Urban Rail Transit Network Planning Scheme [J]. Journal of Systems Engineering and Practice.(3),pp.129-133, (2004).

5. C. Guotai, C. Tingting, Z. Kun. Construction of Evaluation Index System for Human 's Comprehensive Development Based on Correlation

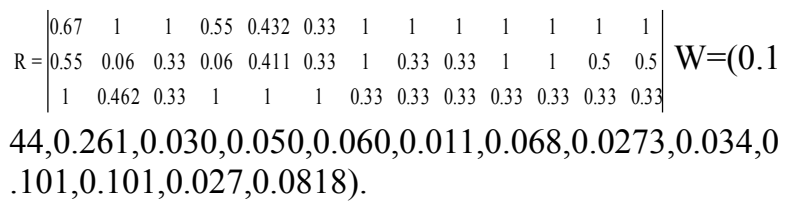

\subsubsection{Integrated decision-making}

$\mathrm{R}^{\prime}=\mathrm{W}^{\mathrm{T}} \mathrm{R}=(0.855,0.481,0.540)$

$\max R^{\prime}=\max \left(r_{1}, r_{2}, r_{3}\right)=\max (0.885,0.481,0.540)=0.885$.

According to the above operation, we can see that the comprehensive decision value of scheme 1 is obviously larger than that of scheme 2 and scheme 3 , so the scheme is optimal;Option 2 is the worst, scenario 3 is second, but there is no obvious superiority compared to scenario 1 . Therefore, the city rail transit network planning theory should choose the first program.

\section{Conclusion}

In this paper, the combination decision-making model of AHP-GRAY,using the Analytic Hierarchy Process to determine the weight of evaluation indicators, taking into account the main and objective factors, the scientific description of the actual problem,Based on the establishment of gray relational decision model, combined with examples, the urban rail transit network planning in the three pre-selection program decision-making, and gives the optimal program.This method provides a simple and convenient method for decision-making of line network scheme.

Principal Component Analysis[J].Systems engineering theory and practice, 32(1),pp. 111-119, (2012).

6. W. Lianfen,et al.An Introduction to Analytic Hierarchy Process[M].Beijing:China Ren min University Press, (1995).

7. T.L. Satty, The Analytic Hierarchy Process: Planning,Priority Setting, Resource Allocation[M]. New York:MC Graw-Hill, Inc., (1980).

8. L. Sifeng, D. Yaoguo, F. Zhigeng.Gray System Theory and Its Application[M]. Beijing:Science Press, (2004).

9. M. Chaoqun, W. Yuping, C. Kuanmin.etal. Comprehensive evaluation for urban rail transit network based on gray weight relation[J].Journal of Chang an University:

Natural Science Edition,(3),pp.84,87,110, (2007)

10. M. Shuhong.Study on the Adaptability of Regional Highway Traffic and Economic Development[D].Chang an University, (2002). 